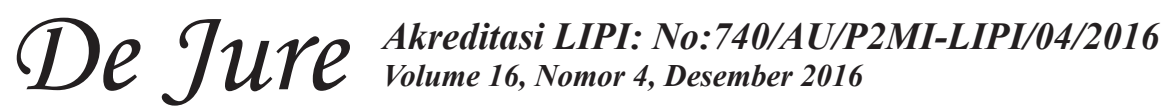

Jurnal Penelitian Hukum De Jure adalah majalah hukum triwulan (Maret, Juni, September dan Desember) diterbitkan oleh Badan Penelitian dan Pengembangan Hukum dan HAM Kementerian Hukum dan HAM RI bekerjasama dengan IKATAN PENELITI HUKUM INDONESIA (IPHI) Pengesahan Badan Hukum Perkumpulan Keputusan Menteri Hukum dan Hak Asasi Manusia Nomor : AHU-13.AHA.01.07 Tahun 2013, Tanggal 28 Januari 2013, bertujuan sebagai wadah dan media komunikasi, serta sarana untuk mempublikasikan aneka permasalahan hukum yang aktual dan terkini bagi para peneliti hukum Indonesia khususnya dan kalangan masyarakat pemerhati hukum pada umumnya.

Penanggung Jawab

Y. Ambeg Paramarta, S.H.,M.Si

(Kepala Badan Penelitian dan Pengembangan Hukum dan Hak Asasi Manusia)

\section{Pemimpin Umum}

Marulak Pardede, S.H.,M.H.,APU

(Ketua Ikatan Peneliti Hukum Indonesia)

\section{Wakil Pemimpin Umum}

T. Daniel L. Tobing, S.H

(Kepala Pusat Pengembangan Data dan Informasi Peneliti Hukum dan Hak Asasi Manusia)

DR. Agus Anwar, S.H.,M.H

(Kepala Pusat Penelitian dan Pengembangan Hukum)

Pemimpin Redaksi

Akhyar Ari Gayo, S.H.,M.H.,APU (Hukum Islam, BALITBANGKUMHAM)

\section{Anggota DewanRedaksi}

DR. Ahmad Ubbe, S.H.,M.H., APU (Hukum Adat, BALITBANGKUMHAM)

Mosgan Situmorang, S.H.,M.H (Hukum Perdata, BALITBANGKUMHAM)

Syprianus Aristieus, S.H.,M.H (Hukum Perusahaan, BALITBANGKUMHAM)

Nevey Varida Ariani, S.H.,M.H (Hukum Pidana, BALITBANGKUMHAM)

Eko Noer Kristiyanto, S.H (Hukum Perdata, BALITBANGKUMHAM)

Muhaimin, S.H (Hukum Islam, BALITBANGKUMHAM)

\section{Redaksi Pelaksana}

Yatun, S.Sos

Sekretaris

M. Virsyah Jayadilaga, S.Si.,M.P

Asmadi

\section{Tata Usaha}

Dra. Evi Djuniarti, M.H

Galuh Hadiningrum, S.H

Suwartono 


\section{TUTe $\begin{aligned} & \text { Akreditasi LIPI: No:740/AU/P2MI-LIPI/04/2016 } \\ & \text { Volume 16, Nomor 4, Desember } 2016\end{aligned}$}

Teknologi Informasi dan Desain Layout

Risma Sari, S.Kom., M.Si (Teknologi Informasi)

Machyudhie, S.T (Teknologi Infornasi)

Saefullah, S.ST.,M.Si (Teknplogi Informasi)

Agus Priyatna, S.Kom (Desain Layout)

Teddy Suryotejo

\section{Mitra Bestari}

Prof. DR. Rianto Adi, M.A (Sosilogi Hukum, UNIKA ATMAJAYA JAKARTA)

Prof. DR. Jeane Neltje Saly, S.H.,M.H (Hukum Humaniter, UNIV. 17 Agustus 1945 Jakarta)

Prof. DR. Hibnu Nugroho, S.H (Hukum Fidana, FH. UNSOED)

DR. Farhana, S.H.,M.H (Hukum Pidana, Fak. Hukum Universitas Islam Jakarta)

DR. Ridwan Nurdin, M.A (Hukum Syariah, Fakultas Syariah Univ. Arraniri Banda Aceh)

DR. Hadi Supratikta (Administrasi Pemerintahan, Balitbang Kemendagri)

\section{Alamat Redaksi:}

Gedung Badan Penelitian dan Pengembangan Hukum dan Hak Asasi Manusia

Kementerian Hukum dan Hak Asasi Manusia Republik Indonesia

Jl. HR. Rasuna Said Kav.4-5, Kuningan, Jakarta Selatan

Telepon, (021)2525015, Faksimili (021) 2526438

Email :

jurnaldejure@yahoo.com

balitbangkumham@gmail.com

ejournaldejure@gmail.com

\section{Percetakan}

PT Pohon Cahaya

Jalan Gedung Baru 18 Jakarta Barat 11440

Telpon (021) 5600111, Faksimili (021) 5670340

Redaksi menerima naskah karya asli yang aktual dalam bidang hukum berupa hasil penelitian dari berbagai kalangan, seperti: peneliti hukum, praktisi dan teoritisi, serta berbagai kalangan lainnya. Tulisan-tulisan yang dimuat merupakan pendapat pribadi penulisnya, bukan pendapat redaksi.

Redaksi berhak menolak, menyingkat naskah tulisan sepanjang tidak mengubah isinya. Naskah tulisan dapat dikirim ke alamat redaksi, maksimum 30 halaman A4, diketik spasi dua rangkap dikirim melalui Email: jurnaldejure@yahoo.com atau melalui aplikasi Open Journal System (OJS) pada URL/website: ejournalbalitbangham.go.id 


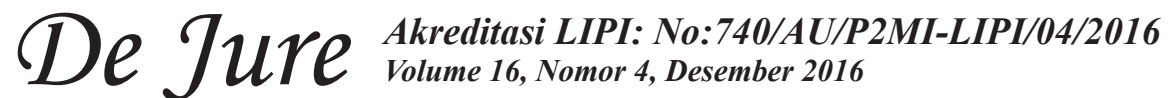

\section{DAFTAR ISI}

\section{DAFTAR ISI}

ADVERTORIAL

Model Pengangkatan Jabatan Pimpinan Tinggi Aparatur Sipil Negara dalam

Perspektif UU Nomor 5 Tahun 2014

(A Model of Position High Leadership Appointment

Of State Civil Apparatus In Perspective Of The Law Number 5 Year 2014)

$411-424$

Ajib Rakhmawanto

DAFTAR RIWAYAT HIDUP

$505-506$

PEDOMAN PENULISAN

507- 508 



\section{De TuPe $\begin{aligned} & \text { Akreditasi LIPI: No:740/AU/P2MI-LIPI/04/2016 } \\ & \text { Volume 16, Nomor 4, Desember } 2016\end{aligned}$}

Puji syukur kehadirat Allah SWT, Jurnal Penelitian Hukum De Jure yang diterbitkan Badan Penelitian dan Pengembangan Hukum dan HAM Kementerian Hukum dan Hak Asasi Manusia bekerjasama dengan Ikatan Peneliti Hukum Indonesia dapat menerbitkan Volume 16 Nomor 4, Desember 2016.

Para pembaca Jurnal Penelitian Hukum De Jure yang tercinta, sebagaimana diketahui bahwa pada tanggal 10 Desember setiap tahunnya diperingati sebagai Hari Hak Asasi Manusia sedunia. Tanggal ini dipilih untuk menghormat Majelis Umum PBB yang mengadopsi dan memproklamirkan Deklarasi Universal Hak Asasi Manusia, sebuah pernyataan global tentang hak asasi manusia pada 10 Desember 1948.

Apabila menilik Hukum dan HAM, merupakan konsepsi kemanusiaan dan relasi sosial yang dilahirkan dari sejarah peradaban manusia di seluruh penjuru dunia. Hukum dan HAM juga dapat dimaknai sebagai hasil perjuangan manusia untuk mempertahankan dan mencapai harkat kemanusiaannya. Agar HAM dapat ditegakkan dalam berbagai kehidupan harus ada instrumen yang mengaturnya. Instrumen tersebut berisi aturanaturan bagaimana HAM itu ditegakkan dan mengikat seluruh warganegara. Sebagai negara yang menjunjung tinggi HAM Indonesia telah memiliki setidak-tidaknya empat instrumen HAM, yakni UUD 1945, TAP MPR Nomor XVII/MPR/1998, UU Nomor 39 Tahun 1999 tentang Hak Asasi Manusia.

Dari beberapa intrumen yang ada tersebut berharap perlindungan dan penegakan HAM kedepanya dapat meningkat, karena masih banyak kekurangan-kekurangan yang harus diperbaiki oleh pemerintah. Seperti lebih difungsikan secara maksimal lembaga-lembaga yang memiliki tugas khusus menegakan HAM.

Dalam rangka memperingati Hari Hak Asasi Manusia Sedunia tersebut, Dewan Redaksi mengangkat tuisan-tulisan dari para peneliti di lingkungan Kementerian Hukum dan HAM yang bersinggungan dengan penegakan Hukum dan HAM di Indonesia.

Akhirnya kami menyampaikan ucapan terima kasih kepada Kepala Badan Penelitian dan Pengembangan Hukum dan HAM Kementerian Hukum dan HAM RI dan Ketua Ikatan Peneliti Hukum Indonesia dalam penerbitan buku ini. Dan juga kami ucapkan terima kasih kepada Prof. DR. Rianto Adi, M.A., Prof. DR. Jeane Neltje Saly, S.H.,M.H., Prof. DR. Hibnu Nugroho, S.H., DR. Farhana, S.H., M.H., DR. Ridwan Nurdin, M.A.,dan DR. Hadi Supratikta, Selaku Mitra Bestari yang telah bersedia membantu memeriksa dan mengoreksi tulisan dari para penulils.

Jakarta, Desember 2016 



\title{
MODEL PENGANGKATAN JABATAN PIMPINAN TINGGI APARATUR SIPIL NEGARA DALAM PERSPEKTIF UU NOMOR 5 TAHUN 2014 (A Model ofPosition High Leadership Appointment Of State Civil Apparatus In Perspective Of The Law Number 5 Year 2014)
}

\author{
Ajib Rakhmawanto \\ Peneliti pada Pusat Pengkajian dan Penelitian, Badan Kepegawaian Negara \\ Jl. Letjen Soetoyo 12 Cililitan Jakarta Timur. Telp: 021.80887011, \\ HP:081310201165 - Email: ajib.bkn@gmail.com, \\ Tulisan Diterima: 9-11-2016; Direvisi: 28-11-2016; \\ Disetujui diterbitkan: 20-12-2016
}

\begin{abstract}
Government administration is required a professional Apparatus Civil Servants (ASN) support. Their professionalism certainly give contribution to government bureaucracy, positively. To create a professional apparatus human resources demand bureaucratic reform of ASN management. The Law of The Republic of Indonesia Number 5 Year 2014 Concerning Apparatus Civil Servants(ASN) mandates a position high leadership appointment of ASN based on merit that supervised by the Commission of Apparatus Civil Servants (independent institution). The purpose of this research is to analysis a model ofposition high leadership appointment of State Civil Apparatus. It is a qualitative descriptive approach. Collecting data by literature research. The research site is at House of Representative of R.I. (Commission II), the Ministry of State Apparatus Empowerment and Bureaucratic Reform, the National Civil Service Agency. Data analysis comes to data reduction, data display, and conclusion. The result of this research shows that the system of position high leadership appointment of State Civil Apparatus carried out by merit system through open bidding starting from administration selection, competency selection, interview, track record research, and health and psychology test that producing three (3) qualifications confirmed one (1) position high leadership by Trustees Personnel Officer.
\end{abstract}

Keywords: Position high leadership, position appointment

\begin{abstract}
ABSTRAK
Dalam penyelenggaraan pemerintahan diperlukan dukungan pegawai ASN yang profesional. Profesionalisme ASN tentunya dapat memberikan kontribusi secara positif bagi birokrasi pemerintahan. Untuk menciptakan sumber daya aparatur yang profesional perlu dilakukan reformasi birokrasi dibindang manajemen ASN. UU Nomor 5 Tahun 2014 Tentang ASN mengamanatkan adanya pengangkatan Jabatan Pimpinan Tinggi ASN berbasis merit yang diawasi lembaga independen (Komisi Aparatur Sipil Negara) KASN. Permasalahan penelitian, bagaimanakah model pengangkatan Jabatan Pimpinan Tinggi Aparatur Sipil Negara? Tujuannya penelitian ini adalah menganalisis model pengangkatan Jabatan Pimpinan Tinggi Aparatur Sipil Negara. Penelitian ini menggunakan pendekatan deskriptif kualitatif. Data penelitian digali dengan teknik studi pustaka (literature). Lokasi penelitian di DPR RI (Komisi II), Kementerian RAN RB, dan BKN. Analisis data melalui tahapan reduksi data, penyajian data, dan penarikan kesimpulan. Hasil penelitian menunjukan sistem pengangkatan JPT ASN dilakukan dengan sistem merit melalui seleksi terbuka mulai dari seleksi administrasi, seleksi kompetensi, tes wawancara, penelusuran rekam jejak, serta tes kesehatan dan psikologi yang menghasilkan 3 (tiga) kualifikasi untuk ditetapkan 1 (satu) JPT oleh Pejabat Pembina Kepegawaian.
\end{abstract}

Kata kunci: Jabatan Pimpinan Tinggi, Pengangkatan Jabatan 


\section{PENDAHULUAN}

Dinamika perubahan lingkungan strategis yang terus berkembang akan mempengaruhi performa birokrasi pemerintahan. Untuk membangun birokrasi pemerintahan yang handal dan kompetitif perlu adanya reformasi birokrasi. Reformasi birokrasi diperlukan sebagai upaya melakukan perubahan mendasar terhadap sistem penyelenggaraan pemerintahan. Tujuannya untuk memperbaiki sendi-sendi birokrasi dari sisi lembaga (organization), tatalaksana (business process), dan SDM aparatur (human capital). Tuntutan reformasi birokrasi lebih banyak disebabkan oleh kesan dan citra buruk dari birokrasi pemerintahan yang belum ditata sesuai dengan kaidah-kaidah nyata dalam birokrasi modern. Berbagai permasalahan dan hambatan yang mengakibatkan sistem penyelenggaraan birokrasi pemerintah tidak efektif, segera ditata ulang dan diperbaiki, sehingga perlu kebijakan pemerintah secara langsung maupun tidak langsung untuk mendukung sistem inovasi efektif (Carolina, 2014:263).

Grand design reformasi birokrasi diperlukan untuk merubah kondisi internal birokrasi dan merespon lingkungan yang terus berkembang. Dalam konteks internal birokrasi pemerintahan, perubahan perlu diarahkan pada; (1) Perampingan organisasi/lembaga, mengingat masih adanya lembaga yang mirip dan menjalankan fungsi yang sama, sehingga terjadi ovelap dalam menjalankan fungsi dan kinerjanya; (2) Penyederhanaan tata kerja, yang masih menimbulkan ketidakjelasan bagi tupoksi aparatur, sehingga berdampak pada pelayanan publik yang kurang efisien; (3) Peningkatan kompetensi Aparatur Sipil Negara (ASN), melihat minimnya keahlian dan keterampilan para pegawai ASN dalam menjalankan tugasnya sebagai pelayan publik (public service). Sedangkan dalam merespon perkembangan lingkungan stratejik, arah dan kecenderungan pola dan paradigma baru birokrasi perlu dijadikan prioritas dalam melakukan reformasi birokrasi, yang diarahkan untuk menciptakan sistem kepegawaian meritokratik (Effendi, 2010:119).

Dalam sistem kepegawaian/manajemen ASN, pola pengembangan ASN harus berubah dan dibenahi mengikuti trend yang di desain sesuai dengan tingkat keahlian dan kompetensinya.
Pegawai ASN harus dikelola secara profesional sebagai aset utama dalam birokrasi pemerintahan. Desain sistem manajemen ASN dibangun dengan perencanaan yang jelas, terarah, dan bebas dari kepentingan apapun, termasuk politik. Problem yang terjadi saat ini justru manajemen ASN banyak digunakan untuk kepentingan politik sesaat, dimana Pejabat Politik (Menteri, Gubernur, Bupati/Walikota) sebagai Pejabat Pembina Kepegawaian (PPK) dalam melakukan promosi atau pengangkatan jabatan ASN tidak didasarkan pada kompetensi dan kualifikasi, tetapi justru dilakukan secara politis. Disamping itu buruknya manajemen kepegawaian salah satunya juga dari efek buruk implementasi otonomi daerah, dimana semakin semena-menannya dalam penempatan pegawai tanpa mempertimbangkan kompetensidan kualifikasi pendidikan pegawai yang bersangkutan (Sugiharta, 2012:238).

Menurut Dwiyanto kompetensi bagi pegawai ASN khususnya Pegawai Negeri Sipil (PNS) menjadi problem tersendiri dalam birokrasi pemerintahan di Indonesia, dimana permasalahan PNS di Indonesia adalah kompetensi bukan pada jumlahnya, rasio PNS dan penduduk masih wajar bahkan bisa dikatakan lebih bagus dibandingkan negara Asia lainnya (Prayoga, 2015: http://www. antaranews.com). Menurutnya yang menjadi pemicu masalah kompetensi adalah pelatihan PNS yang sangat minim, berdasarkan data training rate pada tahun 2013 PNS di Indonesia hanya mendapatkan satu kali pelatihan untuk 26 tahun yang berbanding terbalik dengan negara lain, ini beda jauh dengan Singapura yang melaksanakan pelatihan 100 jam per tahun. Hal itu mengindikasikan perlunya suatu strategy untuk meningkatkan kualitas para pegawai ASN secara keseluruhan.

Disamping itu rendahnya kompetensi juga disebabkan oleh sistem rekrutmen pegawai ASN dan jabatan ASN yang tidak dilaksanakan dengan baik, mengesampingkan prinsip merit, serta penuh praktek Kolusi, Korupsi, dan Nepotisme (KKN). Sebagaimana dikatakan Chaniago bahwa proses rekrutmen jabatan PNS selama ini dinilai terlalu longgar sehingga SDM PNS yang didapatkan sering tidak kompeten dan jika ingin memperbaiki kompetensinya, pemerintah harus memulai dari akarnya yakni merekrut SDM yang benar-benar kompeten(MamDTK, 2012:http://www.rimanews. com). Lebih lanjut Chaniago mengatakan tindakan 


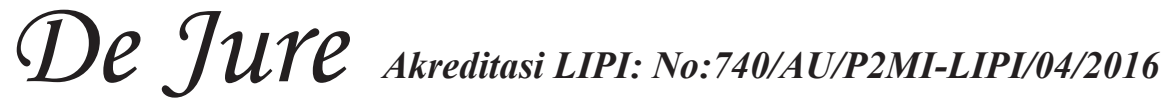

dari akar tersebut harus dibuat gelombang baru, PNS untuk menduduki jabatan direkrut dengan cara yang benar, lalu dilindungi dan diamankan sampai posisi tertentu supaya tidak terkontaminasi virus yang menyebar luas yang menyebabkan kondisi SDM bisa berubah. Metode rekrutmen yang baik sebaiknya diselenggarakan oleh Lembaga Non Pemerintah atau Perguruan Tinggi, sehingga pejabat yang diterima benar-benar yang lulus ujian tanpa diskrimnasi. Sedangkan untuk pejabat lama (tidak kompeten) pemerintah harus berani melakukan pemangkasan, hal ini dinilai perlu demi memberikan ruang bagi gelombang SDM baru yang lebih kompeten.

Lahirnya UU Nomor 5 Tahun 2014 tentang ApatarurSipilNegara sebagaipenggantiUUNomor 43 Tahun 1999 Tentang Perubahan UU Nomor 1 Tahun 1974 Tentang Pokok-Pokok Kepegawaian menjadi jawaban bagi paradigma baru birokrasi dan pemecahan problem ASN. UU Nomor 5 Tahun 2014 salah satunya mengatur tentang sistem manajemen ASN mulai dari penetapan formasi, seleksi/ rekrutmen, penempatan, pengembangan, pengangkatan/promosi dan mutasi, sistem penggajian, sampai pada pemberhentian pegawai ASN. Sebagai subyek dalam pengembangan ASN, maka modal manusia (human capital) selayaknya dinilai pada kompetensi inti (coor competence), kapabilitas (capability), dan proses pembelajaran (learning proces). Sedangkan untuk produktivitas dan peningkatan kinerja ASN, ditekankan pada pengetahuan (knowledge), kemampuan (capability), ketrampilan (skill), sikap (attitudes), perilaku dan etika (behavior and ethics), serta kebiasaan (habit). Hal ini penting karena salah satu tujuan reformasi birokrasi adalah mewujudkan profesionalitas pegawai ASN dengan cara meningkatkan kualitas dan kompetensi.

Kompetensi menjadi syarat mutlak bagi semua pegawai ASN, khususnya mereka yang menduduki jabatan strategis seperti Jabatan Pimpinan Tinggi (JPT). Salah satu substansi pokok UU Nomor 5 Tahun 2014 adalah dihapuskannya jabatan Eselon dalam struktur jabatan karier pemerintahan yang diganti dengan jabatan profesi. Jabatan profesi ASN terdiri atas Jabatan Administrasi, Jabatan Fungsional, dan JPT. JPTmerupakan sekelompok jabatan tertinggi pada instansi yang dikembangkan secara nasional dan direkrut terbuka dengan sistem merit yang diawasi Komisi Aparatur Sipil Negara (KASN).
JPT berfungsi memimpin dan memotivasi setiap pegawai ASN pada instansi pemerintah melalui kepeloporan dan keteladanannya. Pegawai ASN yang akan diangkat/menduduki JPT harus memenuhi persyaratan kualifikasi dan kompetensi sebagaimana persyaratan yang ditentukan dalam jabatan. Mengingat peran dan strategisnya posisi JPT dalam institusi pemerintahan, maka pengangkatan JPT perlu menjadi prioritas dalam manajemen ASN harapannya untuk mendapatkan pejabat yang qualified.

Memperhatikan beberapa praktek penyelenggaraan pemerintahan dalam hal pengangkatan, promosi, dan mutasi jabatan yang masih banyak menuai kritik, tentunya ini menjadi substansi menarik untuk dikaji dan didiskusikan. Problem dalam pengangkatan jabatan, mulai dari sistem seleksi, tim seleksi/baperjakat, politisasi, $\mathrm{KKN}$, kualitas pejabat, dan lain sebagainya. Upaya yang harus dilakukan pemerintahan untuk meminimalisir segala bentuk penyimpangan dalam rangka proses seleksi JPT adalah dengan cara menerapkan sistem merit. Hal ini sebagaimana merujuk pada UU Nomor 5 Tahun 2014 bahwa pengangkatan JPT harus berdasarkan pada asas "merit" yang mendapatkan perbandingan oyektif antara kompetensi, kualifikasi, dan persyaratan yang dibutuhkan oleh jabatan dengan kompetensi, kualifikasi, dan persyaratan yang dimiliki oleh calon JPT. Merit sistem merupakan suatu model perekrutan dimana calon yang lulus seleksi benarbenar didasarkan pada prestasi kerja, kompetensi, keahlian, kemaupunan, dan pengalamannya.

Sebagaimana dikatakan Thoha (2003:107) bahwa konsep merit system menekankan profesionalisme pada pengisian jabatan-jabatan dalam birokrasi pemerintahan, dimana apabila ada seorang pegawai yang mempunyai kompetensi dan keahlian sesuai dengan yang dibutuhkan sesuai dengan suatu jabatan, bisa diangkat untuk menduduki jabatan tersebut. Penerapan sistem merit hakikatnya adanya kesesuaian antara kecakapan yang dimiliki seorang pegawai dengan jabatan yang dipercayakan kepadanya, meliputi tingkat pendidikan formal, tingkat pendidikan non formal/diklatpim, pendidikan dan latihan teknis, tingkat pengalaman kerja, dan tingkat penguasaan tugas dan pekerjaan. Dalam sistem merit keahlian masing-masing individu pegawai akan diorganisasikan secara efektif kedalam suatu spesialisasi fungsi jabatan. Dengan menerapkan sistem merit akan diperoleh pejabat qualified 
yang cakap dan profesional untuk menjalankan tugas dan tanggungjawab jabatan yang diberikan kepadanya.

Konsekuensi dari penerapan merit sistem dalam suatu pengangkatan JPT ASN adalah harus ada standar kompetensi atau tolak ukur kinerja dalam setiap unit organisasi pemerintah atas jabatan tersebut. Tolak ukur kinerja jabatan itu harus dipenuhi oleh alon JPTi sesuai dengan tugas dan tanggungjawab jabatan yang akan didudukinya. Seorang alon JPT wajib mengetahui secara terperinci mengenai pekerjaannya (job descriptions dan job specifications), target kinerja, dan hasil penilaian kinerjanya. Hal ini untuk menjamin obyektivitas antara pekerjaan organisasi dengan calon pejabat yang akan mengerjakan jabatan, sehingga terdapat kesesuaian kompetensi. Disamping menekankan obyektivitas, sistem merit menekankan transparansi atau keterbukaan dalam pengangkatan jabatan, tujuan untuk menciptakan manajemen birokrasi yang transparan. Dalam setiap mengangkatan jabatan ASN khususnya PNS, isu-isu ini selalu menjadi perhatian publik yang menarik untuk dikaji, diteliti, dan didiskusikan. Adapun pokok bahasan dalam penelitian ini membatasi pada permasalahan, bagaimanakah model pengangkatan JPT ASN berbasis merit sebagaimana diamanatkan dalam UU Nomor 5 Tahun 2014? Sedangkan tujuan penelitian adalah menganalisis model pengangkatan JPT ASN sebagaimana diamanatkan dalam UU Nomor 5 Tahun 2014.

\section{METODE PENELITIAN}

Jenis penelitian ini adalah penelitian hukum normatif, yakni penelitian yang dilakukan dengan menganalisis permasalahan dengan menggunakan azas-azas hukum dan prinsip-prinsip hukum atau peraturan perundang-undangan yang terkait dengan masalah peneliti hukum yaitu analisis UU Nomor 5 Tahun 2014 dan Surat Edaran (SE) MENPAN RB Nomor 13 Tahun 2014 Tentang Tata Cara Pengisian JPT Di Lingkungan Instansi Pemerintah. Penelitian akan melihat sejauh mana ketentuan-ketentuan hukum yang menjadi dasar dan landasan bagi permasalahan yang sedang dibahas dengan studi pustaka (library research). Penelitian ini menggunakan pendekatan kualitatif dengan deskriptif analysis, tujuannya untuk menggambarkan fakta dan kondisi atau gejala yang menjadi objek penelitian tentang pengangkatan
JPT ASN, kemudian dilakukan telaah secara kritis untuk memberikan penjelasan-penjelasan atas fakta atau gejala yang terjadi berdasarkan aspek yuridis sebagaimana tertuang dalam UU Nomor 5 Tahun 2014 tentang ASN.

Sumber data penelitian berupa hasil review studi literatur yang digali dari UU Nomor 5 Tahun 2014 Tentang ASN dan Permenpan RB Nomor 13 Tahun 2014 Tentang Tentang Tata Cara Pengisian JPT Di Lingkungan Instansi Pemerintah, Per UU terkait dengan ASN, dokumen-dokumen hasil rapat pembahasan ASN, hasil review bukubuku referensi, jurnal, dan media masa. Teknik pengumpulan datanya dengan mendatangi pusatpusat informasi (perpustakaan) dari berbagai instansi pada lokasi penelitian. Lokasi penelitian dilaksanakan di DPR (Komisi II), Kementerian RAN RB, dan BKN.

Sedangkan teknik pengolahan dan analisis data penelitian ini menggunakan model yang dikembangkan oleh Milles dan Huberman, yaitu melalui tiga jalur kegiatan: pertama, reduksi data; kedua, penyajian data; dan ketiga, penarikan kesimpulan/verifikasi (Sugiyono, (2012:334). Dalam reduksi data, data yang terkumpul disortir dengan memilahkan antara data yang bisa dipakai/ diolah dengan data yang tidak bisa dipakai. Bila ada data yang kurang jelas dan meragukan keabsahannya, maka dilakukan perbaikan atau di edit. Kalau data berhasil diperbaiki maka data akan dipakai dan apa bila data tidak dapat diperbaiki maka data tersebut tidak dipakai.Penyajian (description) data, dilakukan dengan cara menampilkan/memperlihatkan semua data dalam bentuk narasi, tabel, grafik, gambar diagram dari hasil pengolahan data untuk dianalisis. Penarikan kesimpulan dilakukan dengan mempertimbangkan hasil analisis data yang mengarah pada satu kemungkinan besar pada atas keenderungan dari hasil analisis data tersebut.

\section{PEMBAHASAN}

\section{A. Aparatur Sipil Negara dan Jabatan Pimpinan Tinggi}

Aparatur Sipil Negara (ASN) merupakan profesi bagi Pegawai Negeri Sipil (PNS) dan Pegawai Pemerintah Dengan Perjanjian Kerja (PPPK) yang bekerja pada instansi pemerintah, sedangkan pegawai ASN adalah PNS dan PPPK yang diangkat oleh Pejabat Pembina Kepegawaian 


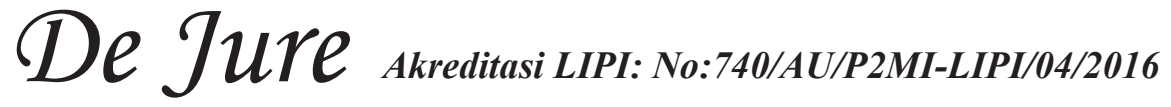

(PPK) dan diserahi tugas dalam suatu jabatan pemerintahan atau diserahi tugas negara lainnya dan digaji berdasarkan peraturan perundangundangan (Pasal 1 UU Nomor 5 Tahun 2014). Pegawai ASN berperan sebagai perencana, pelaksana, dan pengawas penyelenggaraan tugas umum pemerintahan dan pembangunan nasional melalui pelaksanaan kebijakan dan pelayanan publik yang profesional, bebas dari intervensi politik, serta bersih dari praktik KKN. Pegawai ASN diserahi tugas untuk melaksanakan tugas pelayanan publik, tugas pemerintahan, dan tugas pembangunan. Tugas pelayanan publik dilakukan dengan memberikan pelayanan atas barang, jasa, dan pelayanan administratif yang disediakan pegawai ASN. Tugas pemerintahan dilaksanakan dalam rangka penyelenggaraan fungsi umum pemerintahan yang meliputi pendayagunaan kelembagaan, kepegawaian, dan ketatalaksanaan. Tugas pembangunan dilakukan melalui pembangunan bangsa (cultural and political development) serta pembangunan ekonomi dan sosial (economic and social development).

Berdasarkan studi literature, merujuk pada Bab V Pasal 13 UU Nomor 5 Tahun 2014 bahwa jabatan ASN terdiri atas Jabatan Administrasi,Jabatan Fungsional,dan JPT. Jabatan Administrasi adalah sekelompok jabatan yang berisi fungsi dan tugas berkaitan dengan pelayanan publik serta administrasi pemerintahan dan pembangunan. Jabatan Fungsional adalah sekelompok jabatan yang berisi fungsi dan tugas berkaitan dengan pelayanan fungsional yang berdasarkan pada keahlian dan keterampilan tertentu. JPT adalah sekelompokjabatan tinggi pada instansi pemerintah. Jabatan Administrasi terdiri atas 3 (tiga) tingkatan jabatan, yaitu; (a) Jabatan Administrator; (b) Jabatan Pengawas; (c) Jabatan Pelaksana. Jabatan Fungsional terdiri atas 2 (dua) tingkatan jabatan, yaitu; (a) Jabatan Fungsional Keahlian (Utama, Madya, Muda, Pertama); (b) Jabatan Fungsional Keterampilan (Penyelia, Mahir, Terampil, Pemula). JPT terdiri atas 3 (tiga) tingkatan jabatan, yaitu; (a) JPT Utama; (b) JPT Madya; (c) JPT Pratama. Pegawai ASN direkrut untuk menduduki Jabatan Administrasi dan Jabatan Fungsional yang lowong. Pegawai ASN dapat berpindah jalur antar-JPT, administrasi, dan fungsional berdasarkan kualifikasi, kompetensi, dan penilaian kinerja.
Dalam rangka pembinaan dan pengembangan ASN dilakukan penilaian kinerja. Penilaian kinerja pegawai ASN berada di bawah kewenangan Pejabat Yang Berwenang (PYB) pada instansi masing-masing. Penilaian kinerja pegawai ASN didelegasikan secara berjenjang kepada atasan langsung dari pegawai ASN. Penilaian kinerja pegawai ASN dapat juga dilakukan oleh bawahan kepada atasannya. Penilaian kinerja pegawai ASN dilakukan berdasarkan perencanaan kinerja pada tingkat individu dan tingkat unit atau organisasi, dengan memperhatikan target, sasaran, hasil, dan manfaat yang dicapai. Penilaian kinerja pegawai ASN dilakukan secara obyektif, terukur, akuntabel, partisipasi, dan transparan. Hasil penilaian kinerja pegawai ASN disampaikan kepada Tim Penilai kinerja pegawai ASN. Hasil penilaian kinerja pegawai ASN dimanfaatkan untuk menjamin obyektivitas dalam pengembangan ASN, dan dijadikan sebagai persyaratan dalam pengangkatan jabatan dan kenaikan pangkat, pemberian tunjangan dan sanksi, mutasi dan promosi, serta untuk mengikuti diklat.

JPT adalah sekelompok jabatan tinggi pada instansi pemerintah (Pasal 1 UU Nomor 5 Tahun 2014). JPT berfungsi memimpin dan memotivasi setiap pegawai ASN pada instansi pemerintah melalui; (1) Kepeloporan dalam bidang keahlian profesional, analisis dan rekomendasi kebijakan, serta kepemimpinan manajemen; (2) Pengembangan kerja sama dengan instansi lain; (3) Keteladanan dalam mengamalkan nilai dasar ASN dan melaksanakan kode etik dan kode perilaku ASN. JPT hanya dapat diduduki paling lama 5 (lima) tahun dan dapat diperpanjang berdasarkan pencapaian kinerja, kesesuaian kompetensi, dan berdasarkan kebutuhan instansi setelah mendapat persetujuan PPK dan berkoordinasi dengan KASN. PPK dilarang mengganti Pejabat Pimpinan Tinggi selama 2 (dua) tahun terhitung sejak pelantikan, kecuali Pejabat Pimpinan Tinggi tersebut melanggar ketentuan peraturan perundangundangan dan tidak lagi memenuhi syarat jabatan yang ditentukan (Pasal 116 UU Nomor 5 Tahun 2014). Pejabat Pimpinan Tinggi harus netral tidak boleh berpolitik praktis sebagaimana umumnya pegawai ASN.

JPT merupakan konsep baru dalam jabatan di pemerintahan yaitu para pejabat tinggi di instansi (Kementerian/Lembaga/Pemda) yang memiliki peran strategis dalam memastikan tercapainya 
tujuan instansi dan tujuan nasional (Syarien,Media Indonesia: 21 September 2012). Mengingat strategisnya peran JPT, maka penempatan seorang pejabat dalam posisi JPT harus diawasi oleh lembaga yang netral/independen dan masyarakat. Komisi Aparatur Sipil Negara (KASN) merupakan lembaga independen yang melaksanakan pengawasan terhadap pengangkatan JPT ASN. Hal ini sebagaimana tertuang dalam Pasal 32 UU Nomor 5 Tahun 2014 bahwa KASN mepunyai kewenangan mengawasi setiap tahapan proses pengisian JPT mulai dari pembentukan panitia seleksi, pengumuman lowongan, pelaksanaan seleksi, pengusulan nama calon, penetapan, dan pelantikan Pejabat Pimpinan Tinggi. KASN didirikan salah satu tujuannya adalah untuk menjamin terwujudnya sistem merit dalam kebijakan dan manajemen ASN.

\section{B. Sistem Merit}

Douglas Yates menyatakan bahwa ada dua model kontradiktif yang bisa dipergunakan untuk membuat bagaimana pemerintahandapat bekerja dan terstruktur, yaitu model pluralistdemocracy dan model administrative-efficiency, kedua model ini cenderung diartikan sebagai doktrin dalam memerintah sebuah negara atau pemerintahan (Gunawan, 2006: http://redysfer. blogspot.com). Pokok-pokok pemikiran dalam model adminstrative-efficiency menekankan proses kebijakan publik ialah efisiensi, yaitu diperolehnya suatu hasil yang terbesar dengan biaya yang terkecil. Menurut Wasley untuk mewujudkan salah satu tipe ideal birokrasi seperti ini perlu penerapan sistem merit, karena konsep merit sistem secara teoris memiliki keterkaitan dengan model birokrasi administratif efisien (administrative efficiency bureaucracy), hal ini dikarenakan merit sistem menjadi landasan utama bagi birokrasi untuk mengembangkan kemempuan dalam melakukan koordinasi menyeluruh untuk menyerap kepentingan publik secara kuat dan handal (Sunaryo dan Cicellia, 2014:3).

Dalam konsep merit sistem bahwa perbaikan penyelenggaraan birokrasi menjadi hal yang paling utama. Dalam dikotomi merit system dan spoil system, bahwa merit system adalah merupakan konsep yang paling seuai dengan semangat peningkatan kinerja birokrasi dan aparatur. Hal ini mengingat konsep merit system memiliki landasan serta kejelasan kualifikasi, kompetensi, kinerja, dan keadilan yang berkesinambungan. Birokrat dalam birokrasi haruslah seorang pejabat yang profesional, dipilih dan diangkat secara kompetitif berdasarkan kualifikasi dan kompetensinya bukan atas dasar kepentingan politik. Menurut Robert La Folette bahwa merit system is the process of promoting and hiring government employees based on their ability to perform a job, rather than on their political connections (merit sistem adalah proses mempromosikan dan mempekerjakan pegawai pemerintah yang didasarkan pada kemampuan mereka untuk melakukan pekerjaan, bukan pada koneksi politik mereka) (Karepesina, 2011:4-5).

Dalam sistem merit keahlian masing-masing individu pegawai diorganisasikan secara efektif ke dalam suatu spesialisasi fungsi. Secara garis besar paling tidak sistem merit mengupas beberapa hal terkait dengan profesionalisme; Pertama, sistem merit menekankan pada profesionalisme bagi pengisian jabatan birokrasi. Seorang pegawai yang mempunyai kompetensi dan keahlian sesuai persyaratan yang diperlukan oleh suatu jabatan tertentu, dapat diangkat untuk menduduki jabatan tersebut. Namun gejala pengangkatan jabatan ASN di birokrasi pemerintah selama ini justru mengabaikan prinsip merit seperti tidak adanya tes kompetensi, kualifikasi yang tidak jelas, dan banyak politisasi dalam pengangkatan pejabat.Kedua, sistem merit membantu tegaknya birokrasi yang dapat medorong kinerja lembaga pemerintah untuk lebih kompetitif dan inovatif. Namun demikian selama ini penilaian kinerja bagi pegawai ASN justru tidak jelas yang mengakibatkan sulitnya mengukur output kinerja birokrasi pemerintahan.

Terdapat dua prinsip dasar dalam pengangkatan jabatan ASN dengan menerapkan sistem merit. Pertama, adanya transparansi; ini dilakukan sebagai upaya dalam rangka memenuhi tuntutan reformasi yaitu adanya prinsip keterbukaan dalam mekanisme seleksi mulai dari penyampaian informasi jabatan yang lowong, pendaftaran, pelaksanaan tes, pengumuman, pelantikan dan pengambilan sumpah, sampai dengan penempatannya. Prinsip ini bisa dinilai oleh para pegawai dilingkungan kerjanya dan masyarakat pada umumnya, sehingga mereka dapat memberikan penilaian yang lebih obyektif dan rasional. Kedua, adanya akuntabilitas; ini dilakukan mengingat seleksi jabatan akan berkaitan dengan kepentingan masyarakat luas. 


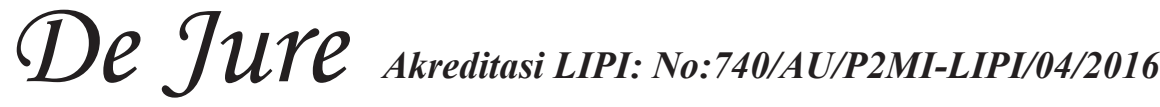

Prinsip ini diambil sebagai pertanggungjawaban kepada publik, karena seluruh tindakan, perbuatan, perilaku, dan aktivitas dalam rangka untuk memenuhi kesejahteraan masyarakat dalam bentuk pelayanan publik.

Upaya untuk meminimalisir segala bentuk penyimpangan dalam rangka proses seleksi jabatan, dengan cara menerapkan sistem merit tersebut. Sistem merit pengangkatan jabatan merupakan suatu model perekrutan jabatan dimana calon yang lulus seleksi benar-benar didasarkan pada prestasi kerja, kompetensi, keahlian, kemaupunan, dan pengalamannya. Hal ini dimaksudkan agar rekrutmen pejabat bersifat spoil system yang lebih menekankan pada hubungan primordial dapat dieliminir. Sebagaimana dikatakan Thoha (2003:107) bahwa sistem merit menekankan aspek profesionalisme pada pengisian jabatan-jabatan dalam birokrasi pemerintahan, dimana apabila ada seorang pegawai yang mempunyai kompetensi dan keahlian sesuai dengan yang dibutuhkan sesuai dengan suatu jabatan, bisa diangkat untuk menduduki jabatan tersebut. Menurutnya, dengan menerapkan sistem merit, maka calon yang lulus seleksi jabatan, pejabat tersebut dijamin memiliki kualitas baik yang dapat mendukung kinerja instansi pemerintah lebih optimal.

\section{Model Pengangkatan Jabatan Pimpinan Tinggi}

Coggburn menekankan bahwa sistem rekrutmen jabatan publik dalam manajemen SDM dimasa mendatang hendaknya memperhatikan prinsip-prinsip civil service yaitu merekrut aparat yang qualified untuk menangani pekerjaanpekerjaan di sektor publik yang bisa memberikan jasa kepada mereka secara adil, pengembangan diri, serta memerlakukan peraturan yang memungkinkan bagi mereka untuk dapat mencapai tujuantujuan publik (Keban, 2008: 111). Lebih lanjut dikatakan Coggburn bahwa dalam merekrut pegawai untuk menduduki suatu jabatan harus mengetahui akan keuntungan dan kerugian dari perspektif politik, manajerial dan legal. Mungkin dari sisi politik teleh melaksanakan nilai-nilai representativeness dan responsiveness, tetapi dari sisi manajerial yang mengutamakan aspek efisiensi, efektifitas dan ekonomi belum terpenuhi. Atau mungkin dari aspek politik dan majerial tidak masalah, akan tetapi dari sisi hukum yang menekankan aspek hak aparat dan keadilan masih menjadi masalah. Selain mempertimbangkan aspek politik, manajerial dan legal tentunya pengangkatan jabatan tidak boleh mengesampingkan aspek kompetensi, oleh karenanya pendekatan sistem merit tetap menjadi prioritas utama.Mengingat peran strategisnya pejabat publik dalam birokrasi pemerintahan, maka pengangkatan jabatan harus dilakukan secara profesional dengan menerapkan prinsip merit.

Hal ini sebagaimana teorinya Weber bahwa tipe ideal birokrasi yang rasional dilakukan dalam cara-cara sbb; (http://irwannoor.lecture.ub.ac.id).

1. Individu pejabat secara personal bebas tetapi dibatasi oleh jabatannya manakala ia menjalankan tugas-tugas atau kepentingan individual dalam jabatannya.

2. Jabatan-jabatan disusun dalam tingkatan hierarki dari atas ke bawah dan ke samping.

3. Tugas dan fungsi masing-masing jabatan dalam hierarki itu secara spesifik berbeda satu sama lainnya.

4. Setiap pejabat mempunyai kontrak jabatan yang harus dijalankan.

5. Setiap pejabat diseleksi atas dasar kualifikasi profesionalitasnya yang dilakukan melalui ujian kompetensi secara kompetitif.

6. Setiap pejabat mempunyai gaji termasuk hak untuk menerima pensiun sesuai dengan tingkatan hierarki jabatan yang disandangnya.

7. Terdapat struktur pengembangan karier yang jelas dengan promosi berdasarkan senioritas dan merit sesuai dengan pertimbangan yang objektif.

8. Setiap pejabat sama sekali tidak dibenarkan menjalankan jabatannya dan resources instansinya untuk kepentingan pribadi dan keluarganya.

9. Setiap pejabat berada di bawah pengendalian dan pengawasan suatu sistem yang dijalankan secara disiplin.

Memperhatikan teori Weber diatas artinya pegawai ASN berhak memperoleh pengembangan kompetensi dan promosi/pengangkatan jabatan secara kompetitif dengan sistem seleksi. Bagipegawai ASN yang memenuhi syarat mempunyai hak yang sama untuk dipromosikan ke jenjang jabatan yang lebih tinggi. Promosi jabatan dilaksanakan dengan mempertimbangkan kinerja, kompetensi, integritas, dan moralitas sebagai bentuk pengembangan karier ASN. Pengangkatan 
jabatan pegawai ASN dilaksanakan berdasarkan hasil penilaian kompetensi, integritas, moralitas oleh tim penilai kinerja pegawai ASN. Pasal 72 UU Nomor 5 Tahun 2014 menyebutkan bahwa promosi jabatan didasarkan pada kebijakan ASN dilakukanberdasarkanperbandinganobjektifantara kompetensi, kualifikasi, dan persyaratan yang dibutuhkan oleh jabatan, penilaian atas prestasi kerja, kepemimpinan, kerja sama, kreativitas, dan pertimbangan dari tim penilai kinerja PNS pada instansi pemerintah, tanpa membedakan jender, suku, agama, ras, dan golongan.

Berdasarkan hasil studi pustaka, merujuk pada Surat Edaran (SE) MENPAN RB Nomor 13 Tahun 2014 Tentang Tata Cara Pengisian JPT Di Lingkungan Instansi Pemerintah, bahwa pengisian JPT harus memperhatikan 9 (sembilan) prinsip sistem merit; (1) Melakukan rekrutmen, seleksi dan prioritas berdasarkan kompetisi terbuka dan adil; (2) Memperlakukan pegawai ASN secara adil dan setara; (3) Memberikan remunerasi yang setara untuk pekerjaan-pekerjaan yang setara dan menghargai kinerja yang tinggi; (4) Menjaga standar yang tinggi untuk integritas, perilaku dan kepedulian untuk kepentingan masyarakat; (5) Mengelola pegawai ASN secara efektif dan efisien; (6) Mempertahankan atau memisahkan pegawai ASN berdasarkan kinerja yang dihasilkan; (7) Memberikan kesempatan untuk mengembangkan kompetensi kepada pegawai ASN; (8) Melindungi pegawai ASN dari pengaruh politis yang tidak pantas/tepat; (9) Memberikan perlindungan kepada pegawai ASN dari hukum yang tidak adil dan tidak terbuka. Sistem pengangkatan JPT harus dilaksanakan secara terbuka, independen, dan profesional.

Dalam konteks NKRI dan dalam rangka mengurangi kooptasi politik, sistem promosi/ pengangkatan JPT dibuka antar instansi, baik Pusat, Provinsi, dan Kabupaten/ Kota dengan mempergunakan instrument Assessment Centre $(A C)$ (Prasojo, Jawa Pos: 30 juli 2012). Sistem promosi jabatan dilakukan dengan memberikan kesempatan kepada setiap calon yang memenuhi syaratkompetensijabatanuntukmelamar.Pengisian JPT dilakukan oleh PPK yang dikoordinasikan KASN dengan adanya panitia seleksi. Jabatan Pimpinan Tinggi hanya dapat diduduki paling lama 5 (lima) tahun. Pejabat Pimpinan Tinggi harus memenuhi target kinerja tertentu sesuai perjanjian kinerja yang sudah disepakati dengan pejabat atasannya sesuai dengan ketentuan peraturan perundang-undangan. Pejabat Pimpinan Tinggi yang tidak memenuhi kinerja selama 1 (satu) tahun pada jabatan, diberikan kesempatan selama 6 (enam) bulan untuk memperbaiki kinerjanya, dan apabila tidak menunjukan perbaikan kinerja yang bersangkutan harus mengikuti seleksi ulang/ uji kompetensi kembali. Berdasarkan hasil uji kompetensi, Pejabat Pimpinan Tinggi dimaksud dapat dipindahkan pada jabatan lain sesuai dengan kompetensi yang dimiliki atau ditempatkan pada jabatan yang lebih rendah.

Pengisian JPT Utama dan Madya pada Kementerian, Kesekretariatan Lembaga Negara, Lembaga Nonstruktural, dan Instansi Daerah dilakukan secara terbuka dan kompetitif secara nasional dari kalangan PNS dengan memperhatikan syarat kompetensi, kualifikasi, kepangkatan, pendidikan dan latihan, rekam jejak jabatan, dan integritas serta persyaratan lain yang dibutuhkan sesuai dengan ketentuan peraturan perundangundangan. Hal ini sebagaimana dilakukan di BKN dalam proses seleksi pengangkanat JPT Madya ASN Deputi Bidang Mutasi Kepegawaian, yang tertuang dalam pengumuman Panitia Seleksi Nomor:01/Peng/Pansel/VIII/2016 dengan ketentuan;

Pertama, pelamaran, yaitu; mengajukan lamaran jabatan yang dipilih, berstatus sebagai PNS, sehat jasmani dan rohani, berusia maksimal 57 (lima puluh tujuh) tahun per tanggal 1 September 2016, memiliki pangkat sekurang-kurangnya Pembina Utama Muda (IV/c), pendidikan minimal Sarjana (S1) diutamakan Pasca Sarjana, sedang/ pernah menduduki JPT Pratama/Fungsional Ahli Utama sekurang-kurangnya 2 (dua) tahun, memiliki pengalaman di bidang kepegawaian dan menguasai peraturan serta kebijakan kepegawaian, mampu berkomunikasi dalam bahasa Inggris, memiliki rekam jejak jabatan, integritas, dan moralitas yang baik, semua unsur penilaian prestasi kerja sekurang-kurangnya bernilai baik dalam 2 (dua) tahun terakhir, telah mengikuti dan lulus Diklat Pimpinan Tingkat II bagi JPT Pratama, telah menyerahkan LHKPN pada jabatan terakhir, persetujuan/rekomendasi dari PPK atau atasan langsung serendah-rendahnya setingkat Pimpinan Tinggi Madya (eselon I), tidak pernah menjalani hukuman disiplin tingkat sedang atau berat dalam 3 (tiga) tahun terakhir, tidak sedang dalam proses peradilan pidana, melampirkan foto copy 


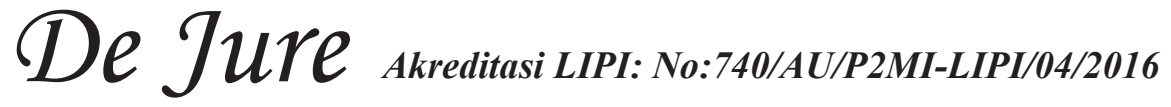

SPT tahun terakhir, dan melengkapi persyaratan lamaran berikut lampiran yang telah ditentukan.

Kedua, kelengkapan berkas, yaitu formulir pendaftaran online Jabatan Pimpinan Tinggi Madya/Pratama yang dicetak dari website seleksijpt.bkn.go.id, surat lamaran yang ditulis tangan sendiri yang dibubuhi materai Rp.6000, formulir Daftar Riwayat Hidup (yang diunduh pada seleksijpt.bkn.go.id) dan ditempel Pas Photo berwarna ukuran $4 \times 6$, formulir persetujuan/ rekomendasi sesuai dengan persyaratan yang ditentukan (yang diunduh pada seleksijpt.bkn. go.id), formulir surat pernyataan tidak sedang menjalani hukuman disiplin dan tidak sedang dalam proses peradilan pidana diketahui oleh pejabat setingkat eselon II yang membidangi

Skema Model Pengangkatan JPT Madya

kepegawaian (yang diunduh pada seleksijpt. bkn. go.id), foto copy ijazah yang dipersyaratkan, foto copy SK Kenaikan Pangkat terakhir, fotocopy SK Pengangkatan dalam Jabatan terakhir, foto copy sertifikat telah lulus pendidikan dan pelatihan kepemimpinan jabatan struktural yang dipersyaratkan, foto copy Penilaian Prestasi Kinerja 2 (dua) tahun terakhir, foto copy SPT tahun terakhir, dan tanda bukti penyerahan Laporan Harta Kekayaan Penyelenggara Negara (LHKPN) dan Laporan Harta Kekayaan Aparatur Sipil Negara (LHKASN). Ketiga, tahapan seleksi, yaitu seleksi administrasi, uji kompetensi kepegawaian menggunakan Computer Assisted Test (CAT), tes bahasa Inggris, uji kompetensi dan Potensi, ujian dan presentasi penulisan makalah, dan ujian presentasi di depan Panitia Seleksi.

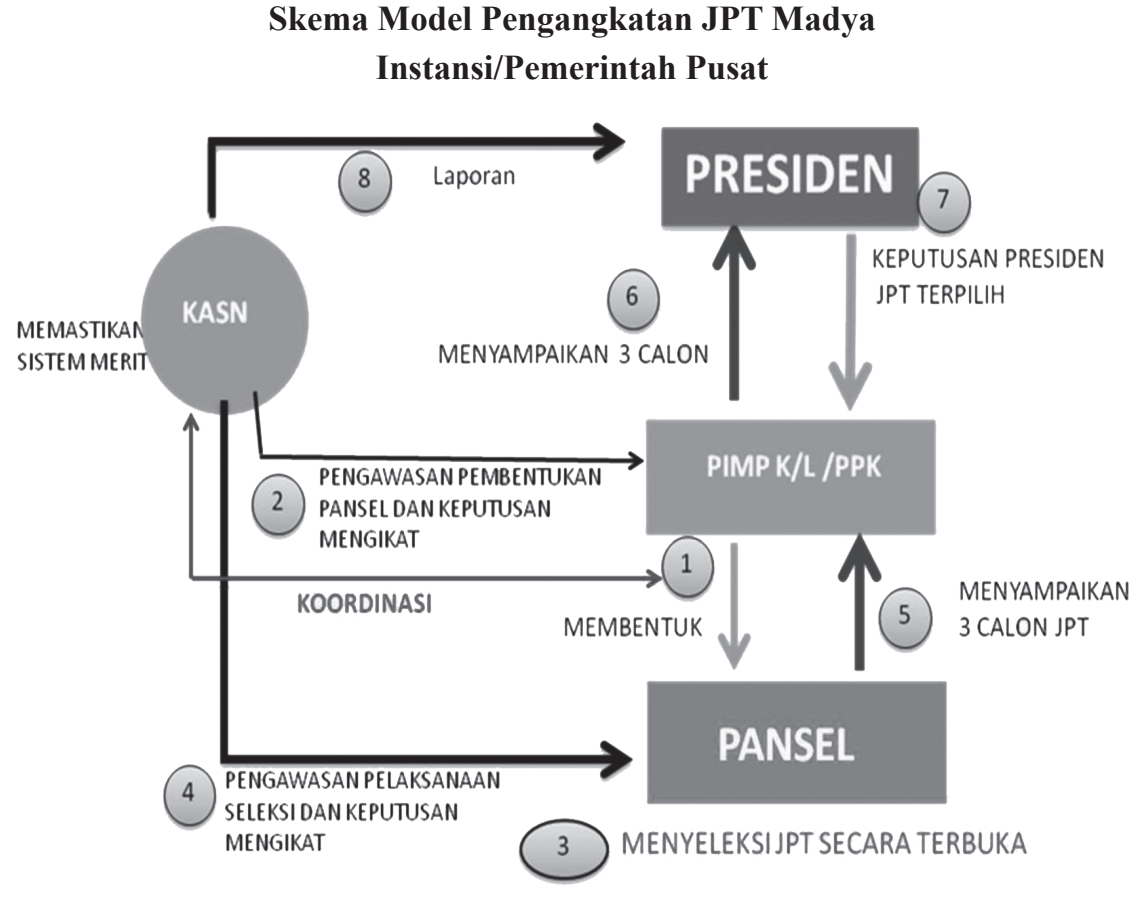

Sedangkan pengisian JPT Pratama dilakukan secara terbuka dan kompetitif antar Kabupaten/ Kota dalam 1 (satu) Provinsi dari kalangan PNS dengan memperhatikan syarat kompetensi, kualifikasi, kepangkatan, pendidikan dan pelatihan, rekam jejak jabatan, dan integritas serta persyaratan jabatan lain sesuai dengan ketentuan peraturan perundang-undangan. Hal ini sebagaimana dilakukan Pemerintah Provinsi Jawa Tengah dalam proses seleksi pengangkanat JPT Pratama ASN Kepala Biro Umum, yang tertuang dalam pengumuman Panitia Seleksi Nomor:01/ Pansel/III/2015 dengan ketentuan;
Pertama, persyaratan umum: PNS usia maksimal 57 per 30 Maret 2015, menduduki atau pernah menduduki JPT Pratama (eselon II.b) atau Administrator (eselon III) atau sedang menduduki jabatan fungsional paling rendah jenjang Madya, masa jabatan paling kurang 2 (dua) tahun dalam eselon yang sama kecuali jabatan fungsional, menduduki pangkat paling rendah Pembina golongan ruang IV/a, berpendidikan paling rendah Sarjana (S.1) atau yang sederajat, telah mengikuti dan lulus Diklat Kepemimpinan Tingkat III, kecuali pejabat fungsional, penilaian DP-3/prestasi kerja SKP paling kurang bernilai baik dalam 2 tahun terakhir, tidak pernah dipidana 
penjara karena melakukan tindak pidana korupsi, tidak sedang menjalani pemeriksaan dugaan pelanggaran disiplin atau sebagai tersangka pelaku tindak pidana, tidak dijatuhi hukuman disiplin tingkat sedang atau berat dalam 2 tahun terakhir, mendapat persetujuan dari atasan langsung bagi PNS Pemerintah Provinsi Jawa Tengah atau Pejabat Pembina Kepegawaian bagi PNS di luar Pemerintah Provinsi Jawa Tengah, Memiliki NPWP dan telah menyampaikan Surat Pemberitahuan Tahunan (SPT) pajak Tahun 2013, dan telah melaporkan LHKPN.

Kedua, persyaratan khusus: berpengalaman dalam pengadaan barang/jasa, perlengkapan, keprotokolan, kerumahtanggaan dan kesekretariatan; menyusun makalah dengan tema "Penguatan Sistem Pelayanan Publik" dengan kajian sesuai dengan tupoksi jabatan Kepala Biro Umum. Ketiga, Tata cara Pendaftaran: pendaftaran dimulai pada tanggal 9 Maret 2015 dan batas akhir pendaftaran pada tanggal 27 Maret 2015 jam 23.59 WIB, pendaftaran dilakukan dengan sistem online ke email sekpanseljpt@ jatengprov. go.id. Langkah pendaftaran selengkapnya, yaitu; (1) membuka website http://www.jatengprov. go.id; (2) me-download kelengkapan persyaratan pendaftaran; (3) mengisi formulir dengan huruf balok dan tinta hitam; (4) me-scan Formulir yang diisi beserta syarat adminitrasi lainnya; melampirkan hasil scan dan kirim melalui email ke alamat: sekpanseljpt@jatengprov.go.id; (6) Pemberitahuan lebih lanjut melalui website http:// www.jatengprov.go.id.

Ketiga, kelengkapan berkas persyaratan administrasi: surat pernyataan mendaftarkan diri, Daftar Riwayat Hidup (DRH), Kartu Tanda Penduduk (KTP), SK Jabatan terakhir, SK pangkat terakhir, Ijazah terakhir, Sertifikat DIKLATPIM Tingkat III bagi pejabat Pimpinan Tinggi Pratama dan Administrator, DP3 atau hasil penilaian prestasi kerja 2 (dua) tahun terakhir, surat keterangan sehat dari dokter Rumah Sakit Pemerintah, surat pernyataan tidak sedang dalam pemeriksaan/hukuman, surat persetujuan dari atasan langsung bagi PNS Pemerintah Provinsi Jawa Tengah atau Pejabat Pembina Kepegawaian bagi PNS di luar Pemerintah Provinsi Jawa Tengah, pas foto berwarna terbaru dengan format jpg dan makalah (soft copy). Semua kelengkapan berkas persyaratan administrasi dikirim dalam bentuk hasil scan. Keempat,tahapan seleksi: pPengumuman dan pendaftaran, seleksi administrasi, pengumuman peserta uji gagasan tertulis, uji gagasan tertulis, pengumuman peserta uji kompetensi, uji kompetensi, pemberitahuan peserta wawancara, wawancara dengan Panitia Seleksi, rekam jejak, penyampaian 3 orang calon hasil seleksi kepada Gubernur Jawa Tengah.

\section{Skema Model Pengangkatan JPT Pratama Instansi/Pemerintah Daerah}

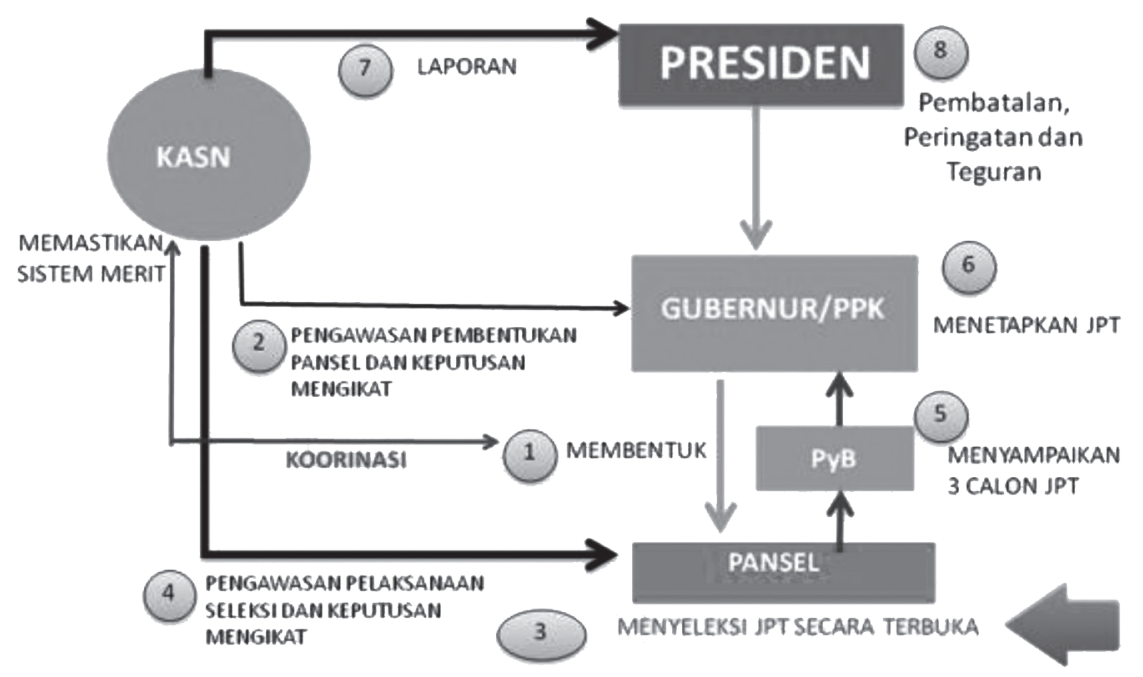




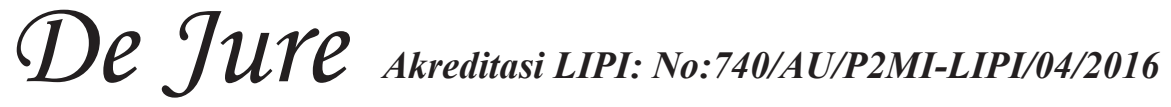

Pegawai ASN yang akan menduduki JPT harus melalui rekrutmen dan tahapan seleksi mulai dari; (1) Persiapan: pembentukan panitia seleksi, penetapan standar kompetensi jabatan, penetapan persyaratan, dan penetapan jadwal seleksi; (2) Pelaksanaan: pengumuman lowongan JPT, seleksi administrasi, seleksi kompetensi, tes wawancara, penelusuran rekam jejak, tes kesehatan dan psikologi, serta mengumumkan hasil seleksi; (3) Monitoring dan evaluasi: Orientasi JPT dan Melaporkan kegiatan ke KASN.

Tahapan Seleksi Pengangkatan

JPT ASN

1. Pembentukan PANSEL

PERSIAPAN

2. Penetapan SKJ, persyaratan, dan jadwal seleksi

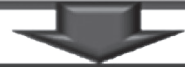

1. PengumumELAKSANAAN

2. Seleksi Administrasi

3. Seleksi kompetensi/asesmen center

4. Wawancara akhir

5. Penelurusan rekam jejak

6. Tes kesehatan dan psikologi (bagi yang direkomendasikan)

7. Pengumuman hasil seleksi

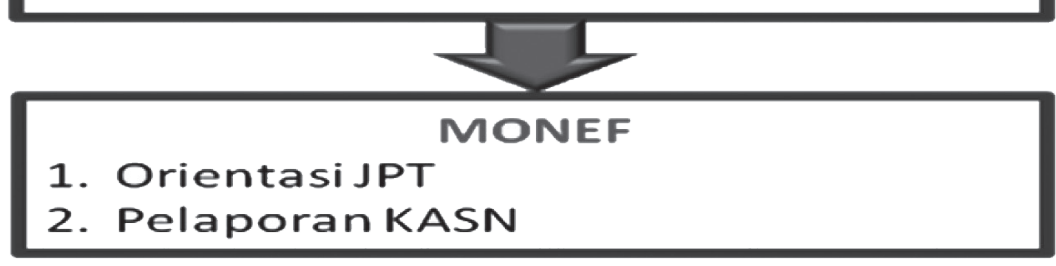

Berikut adalah tahapan seleksi bagi pegawai ASN yang akan menduduki JPT (SE MENPAN RB Nomor 13 Tahun 2014);

\section{Seleksi administrasi;}

a. Penilaian terhadap kelengkapan berkas administrasi yang mendukung persyaratan dilakukan oleh sekretariat panitia seleksi.

b. Penetapan minimal 3 (tiga) calon Pejabat Pimpinan Tinggi yang memenuhi persyaratan administrasi untuk mengikuti seleksi berikutnya.

c. Kriteria persyaratan administrasi didasarkan atas peraturan perundangundangan dan peraturan internal instansi yang ditetapkan oleh PPK masingmasing.

d. Syarat yang harus dipenuhi adalah adanya keterkaitan objektif antara kompetensi, kualifikasi, kepangkatan, pendidikan dan latihan, rekam jejak jabatan, dan integritas serta persyaratan lain yang dibutuhkan oleh jabatan yang akan diduduki.

e. Dilakukan secara online bagi pengumuman pelamaran yang dilakukan secara online.

f. Pengumuman hasil seleksi ditandatangani oleh ketua panitia seleksi.

2. Seleksi kompetensi;

a. Dalam melakukan penilaian kompetensi manajerial diperlukan metode:

1) Untuk JPT Utama, Madya dan Pratama, menggunakan metode $A C$ sesuai kebutuhan masingmasing instansi.

2) Untuk daerah yang belum menggunakan metode $A C$ secara lengkap dapat menggunakan 
metode psikometri, wawancara kompetensi, analisa kasus/ presentasi.

3) Standar kompetensi manajerial disusun dan ditetapkan oleh masing-masing instansi sesuai kebutuhan jabatan dan dapat dibantu oleh Assessor.

4) Kisi-kisi wawancara disiapkan oleh panitia seleksi.

b. Dalam melakukan penilaian kompetensi bidang dengan cara;

1) Menggunakan metode tertulis dan wawancara serta metode lainnya

2) Standarkompetensi bidang disusun dan ditetapkan oleh masing-masing instansi sesuai kebutuhan jabatan dan dapat dibantu oleh Assessor.

3) Standar kompetensi manajerial dan kompetensi bidang ditetapkan oleh masing-masing instansi mengacu pada ketentuan yang ada atau apabila belum terpenuhi dapat ditetapkan sesuai kebutuhan jabatan di instansi masing-masing.

4) Hasil penilaian beserta peringkatnya disampaikan oleh Tim Penilai Kompetensi kepada Panitia Seleksi.

3. Wawancara akhir;

a. Dilakukan oleh panitia seleksi

b. Panitia seleksi menyusun materi wawancara terstandar sesuai jabatan yang dilamar.

c. Wawancara bersifat klarifikasi/ pendalaman terhadap pelamar yang mencakup peminatan, motivasi, perilaku, dan karakter.

d. Dalam pelaksanaan wawancara dapat melibatkan unsur pengguna (user) dari jabatan yang akan diduduki.

4. Penelusuran (rekam jejak) calon;

a. Dapat dilakukan melalui rekam jejak jabatan dan pengalaman untuk melihat kesesuaian dengan jabatan yang dilamar.

b. Menyusun instrumen/kriteria penilaian integritas sebagai bahan penilaian utama dengan pembobotan untuk mengukur integritasnya.

c. Apabila terdapat indikasi mencurigakan dilakukan klarifikasi dengan instansi terkait.

d. Melakukan penelusuran rekam jejak ke tempat asal kerja termasuk kepada atasan, rekan sejawat, dan bawahan dan lingkungan terkait lainnya.

e. Menetapkan pejabat yang akan melakukan penelusuran rekam jejak secara tertutup, obyektif dan memiliki kemampuan dan pengetahuan teknis intelejen.

f. Melakukan uji publik bagi jabatan yang dipandang strategisjika diperlukan.

\section{Hasil Seleksi;}

a. Panitia seleksi mengolah hasil dari setiap tahapan dan menyusun peringkat nilai.

b. Panitia seleksi mengumumkan hasil dari setiap tahap kepada peserta seleksi.

c. Panitia seleksi menyampaikan peringkat nilai kepada PPK.

d. Peringkat nilai yang disampaikan kepada PPK bersifat rahasia.

e. Panitia seleksi menyampaikan hasil penilaian JPT Utama dan Madya (setara dengan Eselon Ia dan Ib) dan memilih sebanyak 3 (tiga) calon sesuai urutan nilai tertinggi untuk disampaikan kepada PPK (Menteri/Pimpinan Lembaga/ Gubernur).

f. PPK (Menteri/Pimpinan Lembaga/ Gubernur)mengusulkan 3 (tiga) nama calon yang telah dipilih panitia seleksi kepada Presiden.

g. Panitia Seleksi menyampaikan hasil penilaian JPT Pratama (setara dengan Eselon IIa dan IIb) dan memilih sebanyak 3 (tiga) calon sesuai urutan nilai tertinggi untuk disampaikan kepada Pejabat Yang Berwenang.

h. Pejabat Yang Berwenang mengusulkan 3 (tiga) nama calon yang telah dipilih panitia seleksi kepada PPK (Menteri/ Pimpinan Lembaga/Gubernur/ Bupati/ Walikota). 


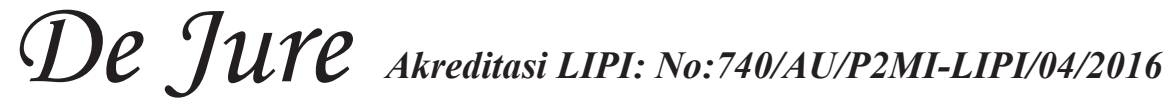

i. Penetapan calon harus dilakukan konsisten dengan jabatan yang dipilih dan sesuai dengan rekomendasi panitia seleksi kecuali untuk jabatan yang serumpun.

\section{Tes kesehatan dan psikologi;}

a. Tes kesehatan dan psikologi dapat dilakukan bekerjasama dengan unit pelayanan kesehatan pemerintah dan lembaga psikologi.

b. Peserta yang dinyatakan lulus wajib menyerahkan hasil uji kesehatan dan psikologi.

\section{KESIMPULAN}

Hasil penelitian menunjukan bahwa model pengangkatan JPT berbasis merit dilaksanakan secara terbuka, independen, dan profesional yang memberikan kesempatan kepada setiap calon yang memenuhi syarat kompetensi jabatan untuk melamar. Pengangkatan JPT melibatkan KASN yang dilakukan dengan menerapkan sistem merit melalui seleksi terbuka, mulai dari seleksi administrasi, seleksi kompetensi, tes wawancara, penelusuran rekam jejak, serta tes kesehatan dan psikologi. Sebagaimana dilakukan Pemerintah Provinsi Jawa Tengah dan BKN, pengangkatan JPT dibuka antar instansi, baik Pusat, Provinsi, Kabupaten, dan Kota dengan menerapkan sistem merit yang mendasarkan pada perbandingan objektif antara kompetensi, kualifikasi, dan persyaratan yang dibutuhkan oleh jabatan, penilaian prestasi kerja, kepemimpinan, kerja sama, kreativitas, dan pertimbangan tim penilai kinerja. Sebelum pengisian JPT, PPK membentuk Panitia Seleksi terdiri dari unsur internal maupun eksternal instansi pemerintah yang diangkat berdasarkan pengetahuan, pengalaman, kompetensi, rekam jejak, integritas moral, dan netralitas melalui proses terbuka. Berdasarkan hasil seleksi, Panitia Seleksi merekomendasikan 3 (tiga) calon JPT yang lolos seleksi/memenuhi kualifikasi kepada PPK untuk ditetapkan 1 (satu) JPT. JPT hanya dapat diduduki paling lama 5 (lima) tahun dan dapat diperpanjang berdasarkan pencapaian kinerja, kesesuaian kompetensi, dan berdasarkan kebutuhan instansi setelah mendapat persetujuan PPK dan persetujuan KASN.

\section{SARAN}

Untuk menyempurnakan pengangkatan JPT ASN perlu adanya peraturan yang jelas, antara jumlah/prosentasi Panitia Seleksi JPT yang berasal dari unsur intern instansi pemerintah dan ekstern instansi pemerintah, serta kriterianya. Seleksi dan pembentukan Panitia Seleksi JPT sebaiknya dilakukan oleh Pejabat Yang Berwenang (PYB) bukan PPK, hal ini mengingat PPK merupakan pejabat politik sedangkan JPT pejabat kaier, hal ini rentan terhadap kepentingan politik. Sebaiknya dibuat aturan yang baku dan komitmen bersama atas konsekuensi logis terhadap hasil seleksi jabatan, apabila PPK tidak mau memilih/melantik dari 3 (tiga) calon JPT yang lolos seleksi dan memenuni kualifikasi. JPT masa kerjanya hanya 5 (lima) tahun yang dapat diperpanjang berdasarkan pencapaian kinerja, kesesuaian kompetensi, dan kebutuhan instansi, hal ini perlu dibuat kriteria dan regulasi yang jelas agar tidak menimbulkan banyak penafsiran. Mengingat pengangkatan JPT berasis merit, ketentuan/peraturan dan syarat administrasi yang membatasi/mengatur tentang seperti persyaratan pangkat, golongan, masa kerja, umur, dan lain sebagainya sudah tidak relevan lagi. 


\section{DAFTAR KEPUSTAKAAN}

Carolina, Ari Sudaryanto, Arief Setyabudhi, (2014),Pusyantek Sebagai Komponen Layanan Ekosistem Inovasi Untuk Pemberdayaan UMKM, Inovasi Jurnal Politik dan Kebijakan, Volume 11 Nomor 4 Desember 2014,Hlm 263

Effendi, Sofian, Reformasi Tata Pemerintahan: Menyiapkan Aparatur Negara Untuk Mendukung Demokratisasi Politik dan Ekonomi Terbuka, Yogyakarta: Gadjah Mada University Press, 2010

Gunawan, R. Hendra, Urgensi Reformasi Birokrasi Bagi Percepatan Pemberantasan Korupsi (Online), Dari: http://redysfer.blogspot. co.id/2006_03_01_archive.html. Diakses: 23 September 2015

Karepensina, M Tahir, Merit Sistem Dalam Penempatan Pegawai Pada Dinas Pendidikan dan Kebudayaan Kabupaten Buru, Tesis (S2) tidak diterbitkan, Makassar: Universitas Hasanudin, 2011

Keban, Yeremias T, Enam Dimensi Strategis Administrasi Publik Konsep Teori dan Isu, Yogyakarta: Gava Media, 2008

Mam DTK, Mayoritas Kinerja PNS Buruk, Sistem Rekrutmen Harus Direformasi (Online). Dari: http://www.rimanews. $\mathrm{com} / \mathrm{read} / 20120302 / 55863 /$ mayoritas kinerja-pns-buruk-sistem-rekrutmen-harusdireformasi. Diakses: 10 Mei 2014

Noor, Irwan, Birokrasi Weber Dalam Perspektif Administrasi Publik (Online). http:// irwannoor.lecture.ub.ac.id/2012/05/ birokrasi-weber/. Diakses: 11 Juli 2016

Prasojo, Eko, Mengubah Kultur Birokrasi, Jawa Pos 30 Juli 2012, Hlm 7

Prayoga, Ricky,Pakar: Permasalahan PNS Adalah Kompetensi (Online). Dari http://www. antaranews.com/berita/494973/pakarpermasalahan-pns-adalah-kompetensi. Diakses: 19 Juli 2015

Ruky, Ahmad. S, Sumber Daya Manusia Berkualitas Mengubah Visi Menjadi Realitas, Jakarta: PT Gramedia Pustaka Utama, 2006
Sugiharta, Sri, Desentralisasi dan Sumber Daya Aparatur: Problematika Pelaksanaan Desentralisasi Pelestarian Cagar Budaya di Provinsi Sumatera Barat, Riau, dan Kepulauan Riau. Jurnal Ilmu Sosial dan Ilmu Politik, Volume 15, Nomor 3, Maret 2012, Hlm 238

Sugiyono. Metode Penelitian Administrasi. Bandung: Alfa Beta. 2012

Sunaryo, Bambang dan Cicellia Celly,Nilai Penting Konsep Affirmative Action Policy Dalam Pengemangan SDM Aparatur Berbasis Merit, Civil Service Jurnal Kebijakan dan Manajemen PNS, Volume 8 Nomor 1 Juni 2014, Hlm 3

Syarien, Alfie, RUU Aparatur Sipil Negara, Revolusi Yang Dibutuhkan,Media Indonesia 21 September 2012, Hlm 5

Surat Edaran (SE) MENPAN RB Nomor 13 Tahun 2014, Tentang Tata Cara Pengisian JPT Di Lingkungan Instansi Pemerintah

Toha, Miftah, Birokrasi Dan Politik Di Indonesia, Jakarta:PT Raja Grafindo Persada, 2003

Undang-Undang Nomor 5 Tahun 2014, Tentang Aparatur Sipil Negara 


\section{De JuYe akreditasi LIPI: No:740/AU/P2MI-LIPI/04/2016}

\section{BIODATA PENULIS}

Nama, Ajib Rakhmawanto, S.IP., M.Si., lahir di Yogyakarta 10 April 1972. Menamatkan pendidikan Sarjana/S.1 (S.IP) Jurusan Ilmu Hubungan Internasional di Universitas Muhammadiyah Yogyakarta pada tahun 2007. Menamatkan pendidikan Pascasarjana/S.2 (M.Si) Jurusan Ilmu Administrasi Negara di Program Pascasarjana Universitas Gadjah Mada Yogyakarta pada tahun 2003. Menempuh pendidikan Pascasarjana/S.3 (Doktor) Jurusan Ilmu Administrasi Publik di Program Pascasarjana Universitas Padjajaran Bandung mulai tahun 2013. Bekerja sebagai peneliti (researcher) pada Pusat Pengkajian dan Penelitian Badan Kepegawaian RI di Jakarta. 


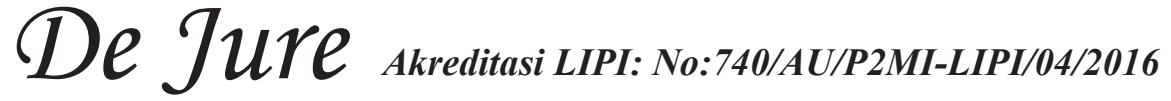

\section{PEDOMAN PENULISAN NASKAH JURNAL PENELITIAN HUKUM DE JURE}

1. Naskah yang dimuat dalam Jurnal Penelitian Hukum De Jure adalah tulisan yang belum pernah dipublikasikan dalam media massa.

2. Naskah yang dimuat dalam Jurnal Penelitian Hukum De Jure meliputi tulisan tentang hasil penelitian (penelitian empiris maupun penelitian normatif atau studi dokumenter), pemikiran dan informasi lain yang bersifat ilmiah.

3. Menggunakan bahasa Indonesia yang baku.

4. Sistimatika Penulisan :

A. Naskah artikel hasil penelitian empiris :

o Judul aktual

Menggambarkan isi naskah dan maksimal 14 kata ditulis dalam bahasa Indonesia dan Inggris

o Nama penulis

Tanpa gelar akademik, jabatan, kepangkatan, alamat lembaga/instansi dan e-mail

o Abstrak

Berisi Latar Belakang, Rumusan Masalah, Tujuan, Kegunaan, Metode, Isi

Pembahasan, Analisis, Kesimpulan dan Saran Temuan ditulis dalam satu spasi;

150 kata (10-20 baris/ satu (1) paragraf) diketik menggunakan huruf Times New

Roman; font 11 italic; ditulis dalam bahasa Indonesia dan bahasa Inggris.

o Kata Kunci

Mengandung yang di indekskan ditulis dalam bahasa Indonesia dan Inggris

dengan minimal 3 kata maksimal 5 kata

- PENDAHULUAN

Berisi latar belakang masalah dan rumusan masalah, tujuan, kegunaan, kerangka Teori/Konsep, Metode (metode penelitian yang digunakan, di antaranya meliputi jenis penelitian, lokasi penelitian, sumber data, teknik pengumpulan data, pengolahan data dan analisis data.)

- PEMBAHASAN

Berisi, pembahasan terhadap masalah yang diteliti

- Analisis

Berisi analisis dari semua pokok pembahasan

- PENUTUP

Kesimpulan dan saran

Kesimpulan dan saran ditulis dalam bentuk uraian bukan dalam bentuk'angka

- DAFTAR KEPUSTAKAAN

Daftar Pustaka : ditulis berdasarkan abjad, dengan urutan : Nama pengarang. Judul buku. Kota penerbit: nama penerbit, tahun penerbitan.

Contoh ....Hamzah. Andi, Bantuan Hukum suatu Tinjauan Yuridis. Ghalia

Indonesia, Jakarta, 1983. 


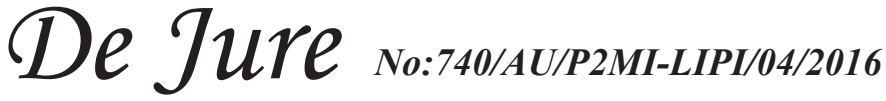

B. Naskah artikel ulasan Hasil penelitian normatif atau studi dokumenter), pemikiran dan informasi lain yang bersifat ilmiah.

o Judul aktual

Menggambarkan isi naskah dan maksimal 14 kata ditulis dalam bahasa

Indonesia dan Inggris

o Nama penulis

Tanpa gelar akademik, jabatan, kepangkatan, alamat lembaga/instansi dan e-mail

o Abstrak

Berisi Latar Belakang, Rumusan Masalah, Tujuan, Kegunaan, Metode, Isi

Pembahasan, Analisis, Kesimpulan dan Saran Temuan ditulis dalam satu spasi;

150 kata (10-30 baris/ satu (1) paragraf) diketik menggunakan huruf Times

New Roman; font 11 italic; ditulis dalam bahasa Indonesia dan bahasa Inggris

o Kata Kunci

Mengandung yang di indekskan ditulis dalam bahasa Indonesia dan Inggris

minimal 3 kata maksimal 5 kata

- PENDAHULUAN

Latar belakang masalah dan rumusan masalah

- PEMBAHASAN

Berisi, pembahasan terhadap masalah yang dikaji

- ANALISIS

Berisi analisis dari semua pokok pembahasan

- PENUTUP

Kesimpulan Dan Saran

Kesimpulan dan saran ditulis dalam bentuk uraian bukan dalam bentuk angka

- DAFTAR KEPUSTAKAAN

Daftar Pustaka : ditulis berdasarkan abjad, dengan urutan : Nama pengarang. Judul buku. Kota penerbit : nama penerbit, tahun penerbitan.

Contoh ....Hamzah. Andi, Bantuan Hukum suatu Tinjauan Yuridis. Ghalia

Indonesia, Jakarta, 1983.

5. Naskah dilengkapi dengan indeks.

6. Naskah diketik rapi 1,5 spasi di atas kertas A4; menggunakan huruf Times New Roman; Font 11; antara 20-30 halaman; diprint out dan disertai soft copy CD.

7. Penulisan kutipan sumber rujukan dengan sistem bodynote, yaitu menulisk ${ }^{\wedge} \mathrm{n}$ nama pengarang (tanpa gelar akademik); tahun penerbitan dan no halaman, yang ditulis dalam kurung; diletakan dibelakang kutipan. Contoh : .(Hamzah, 2007: 15)

8. Isi tulisan di luar tanggungjawab redaksi. Dan redaksi berhak mengedit redaksional tanpa merubah arti.

9. Naskah yang belum memenuhi syarat akan dikonfirmasikan atau dikembalikan untuk diperbaiki.

10. Keterangan lengkap dapat menghubungi redaksi Jurnal Peneltian Hukum De Jure melalui Email: jurnaldejure@yahoo.com 
